University of Nebraska - Lincoln

DigitalCommons@University of Nebraska - Lincoln

\title{
Population Dynamics of the Western Prickly Pear, Opuntia macrorhiza (Cactaceae)
}

Kathleen H. Keeler

University of Nebraska - Lincoln, kkeeler1@unl.edu

Brigitte Tenhumberg

University of Nebraska - Lincoln, btenhumberg2@unl.edu

Follow this and additional works at: https://digitalcommons.unl.edu/bioscifacpub

Part of the Biodiversity Commons, Plant Sciences Commons, Population Biology Commons, and the Terrestrial and Aquatic Ecology Commons

Keeler, Kathleen H. and Tenhumberg, Brigitte, "Population Dynamics of the Western Prickly Pear, Opuntia macrorhiza (Cactaceae)" (2011). Faculty Publications in the Biological Sciences. 183.

https://digitalcommons.unl.edu/bioscifacpub/183

This Article is brought to you for free and open access by the Papers in the Biological Sciences at DigitalCommons@University of Nebraska - Lincoln. It has been accepted for inclusion in Faculty Publications in the Biological Sciences by an authorized administrator of DigitalCommons@University of Nebraska - Lincoln. 


\title{
POPULATION DYNAMICS OF THE WESTERN PRICKLY PEAR, OPUNTIA MACRORHIZA (CACTACEAE)
}

\author{
Kathleen H. Keeler* and Brigitte Tenhumberg
}

\author{
School of Biological Sciences, University of Nebraska-Lincoln, Lincoln, NE 68588-0118 \\ *Correspondent: kkeeler1@unl.edu
}

\begin{abstract}
Although most cacti that have been studied are long lived, following individually marked plants in Boulder County, Colorado, for $>7$ years, we determined that average life span of Opuntia macrorhiza, the western prickly pear, is 3 years. A few individuals probably live $>10$ years. Vegetative reproduction, produced by rooting of cladodes, exceeded reproduction by germination and establishment from seeds. Both types of new recruits, from vegetative reproduction and seeds, had higher death rates than established plants. Size and frequency of flowering increased with age, although size both increased and decreased, sometimes dramatically, between years. Flowering correlated more strongly with size than with age. Estimates of population growth indicated these populations were stable $(\lambda=1.02)$. Elasticities suggest that the population was most sensitive to survival of smaller plants.
\end{abstract}

RESUMEN-Si bien la mayoría de los cactus estudiados son perennes, luego del seguimiento por más de 7 años de plantas marcadas individualmente en el condado de Boulder en Colorado, encontramos que el promedio de vida de plantas de Opuntia macrorhiza, el nopal raizudo, es de 3 años. Pocos individuos probablemente viven más de 10 años. La multiplicación vegetativa a través del enraizamiento de cládodes excedió a la reproducción por germinación y establecimiento a partir de semillas. Ambos tipos de nuevos reclutas, sean provenientes de multiplicación vegetativa o de semillas, evidenciaron mayores tasas de mortandad que las plantas ya establecidas. El tamaño y frecuencia de floración aumentaron con la edad, pero el tamaño de plantas aumentó y decreció, a veces notablemente, entre años. La floración se correlacionó más fuertemente con tamaño que con edad. Las estimaciones de crecimiento poblacional indicaron que estas poblaciones fueron estables $(\lambda=1.02)$. Las elasticidades sugieren que la población fue más sensible a la supervivencia de las plantas más pequeñas.

There are ca. 1,500 species of cacti; many species grow slowly, flower infrequently, and live a long time, which matches predictions for specialist xeriphytes (Godínez-Álvarez et al., 2003). For instance, cardón (Cephalocereus columnatrajani) may live $>145$ years (Zavala-Hurtado and Díaz-Solis, 1995) and Neobuxbaumia macrocephala >200 years (Esparza-Olguín et al., 2002). Even tiny button-like Corypantha robbinsorum were estimated to average 17 years of age (Schmalzel et al., 1995). Despite species richness of cacti, there are relatively few demographic studies of cacti (Godínez-Álvarez et al., 2003; Valverde and Zavala-Hurtado, 2006; Mandujano et al., 2007). Demographic studies are important to evaluate viability of populations and species and guide management decisions. For instance, Rae and Ebert (2002) documented a decreasing population trend of the rare Florida species Harrisia fragrans, and extinction was expected in
$<20$ years, primarily due to failure of recruitment. Because of environmental stochasticity long time series are necessary to detect such trends, but unfortunately, they are not available for many herbaceous species and communities. This study reports on an 8-year demographic study of Opuntia macrorhiza, the western prickly pear.

Opuntia is in the Cactaceae and contains ca. 150 species (Pinkava, 2003) that are generally dry-habitat specialists. The genus is native to the New World, but some species introduced elsewhere have naturalized and are invasive (Benson, 1992; Pinkava, 2003; Reyes-Agüero et al., 2006). Many species of Opuntia live for a long time; e.g., Mandujano and coworkers (Mandujano et al., 1996, 1998, 2001) reported that Opuntia rastrera (nopal) lived for decades. This species dominates the nopal ecosystem through its long life span and ability to reproduce vegetatively by 
rooting of cladodes (Mandujano et al., 1998). Another Opuntia known to be long-lived is $O$. engelmanii, which lived an average of 20 years in the Sonoran Desert (Bowers, 1996). For most species, ages are not known but are inferred from size of plants (e.g., Godínez-Álvarez et al., 2003; Reyes-Agüero et al., 2006).

In this study, we describe reproductive patterns, estimate life expectancy, and rates of growth of populations of $O$. macrorhiza. This species is a common cactus of the plains, Rocky Mountain foothills, and Great Basin of the United States ranging southward into northern Mexico (Chihuahua; Benson, 1992; Anderson, 2001; Pinkava, 2003). It is an endangered species in Iowa and salvage-restricted in Arizona (United States Department of Agriculture Natural Resources Conservation Service, http:plants.usda. gov).

Materials and Methods-We mapped and measured plants of Opuntia macrorhiza var. macrorhiza annually in five plots in the Open Space and Mountain Parks, Boulder, Boulder County, Colorado. The study was conducted 1998-2005, although some plants were observed in1995. Numbering of plots conformed to the permanent plot system of J. and C. Bock (Bennett, 1997; Bock and Bock, 1998). Three plots (28, 57, and 61) were flat with gravelly soil. One plot (52) had similar soil but was on a hilltop (Davidson Mesa). The fifth plot (102), in Chataqua Park Meadow, was on a grass-covered east-facing slope. Two plots (28 and 61) were grazed by cattle in summer, one plot (52) was grazed in winter, and two plots (57 and 102) were not grazed. All plots were $100 \mathrm{~m}^{2}$ except one (57), which was $92 \mathrm{~m}^{2}$ and had the highest density and absolute number of plants.

New plants were added to the study when they appeared within the plots. Cladodes of O. macrorhiza can root when separated from the plant (Benson, 1992). Following Mandujano et al. (1998), we counted adjacent cladodes as two plants if they were not physically connected. This was the most-parsimonious definition and ensured straightforward comparison of both studies. Thus, we defined a plant as a physiologically independent unit. The same genotype could occur in many plants.

Beginning in 1999, we estimated size of plants by counting cladodes. Bowers (1996) determined that number of cladodes was a good indicator of flowering and vegetative growth in the similar species $O$. englemannii. Single cladodes of $O$. macrorhiza can be 1-10 cm in length, so biomass of plants does not follow number of cladodes in any simple fashion. Plants can increase in size exponentially because new cladodes are produced from buds atop each cladode. Consequently, our size classes of cladodes were 1, 2-3, $4-7,8-15$, and $>15$.

We recorded deaths. Ideally, we would find a white cladode, dry and badly damaged, at the site where the plant was recorded the previous year. Plants that were entirely yellow were conservatively recorded as present and alive. Absence of $O$. macrorhiza where one was recorded the previous year was noted as death of the plant. In a few instances, the plant may have been kicked by cattle and moved to a new location, and so be falsely reported as dead. However, most vegetative reproduction occurred close to the parent plant because big cladodes do not easily move far and the long spines of O. macrorhiza are not barbed enough to cling.

We estimated flowering effort of each plant by counting buds, flowers, and fruits. We usually made only 1 survey/plot/year, late enough to count developing fruits. Consequently, we have undercounted flowering effort by missing flowers that did not result in seeds.

We analyzed survival with Cox proportional-hazards models (Cox and Oakes, 1984; Kalbfleish and Prentice, 1990). Plants for which we did not know date of germination, date of death, or both, were included as censored data; e.g., if a plant for which we do not know date of germination died in the fourth year of our study, we knew that this plant had lived $\geq 4$ years. Censoring allowed us to include this information in the analysis. Plants with unknown germination were leftcensored data, plants that were still alive at the end of the study were right-censored data, and plants with unknown date of germination and that were still alive at the end of the study were interval censored. In Cox proportional-hazards models, the observed rate of hazard is the product of a baseline hazard and a factor that gives the joint effect of a set of covariates $z_{1}, \ldots ., z_{p}$. General form of the model is:

$$
h(t, z)=\lambda_{0}(t) \exp \sum_{i=1}^{p}\left(\beta_{i} z_{i}\right)
$$

where $h(t, z)$ denotes the observed rate of hazard, $\lambda_{0}(t)$ is the baseline hazard, $t$ is time since the last sample, and $\beta_{1}, \ldots \beta_{\mathrm{p}}$ are relative contributions of covariates. Our sample was too small to include a year effect, so we only included plot as a covariate. Survival analysis was performed in R (Version 1.8.0; R Development Core Team, 2006).

We calculated mean and median sizes of plants using Microsoft Excel. We tested for correlations among plots, between number of plants and annual precipitation (National Oceanographic and Atmospheric Administration, 1995-2005), and between number of cladodes and age using Microsoft Excel. We compared distance from an established plant to recruits from seeds and vegetative recruits using the $t$-test in Microsoft Excel. Correlations between number of cladodes and number of fruits were calculated using SAS CORR (SAS Institute, Inc., Cary, North Carolina).

We developed a size-structured, Lefkovitch-matrix model that accounts for plants decreasing in size from one year to the next (Caswell, 2001). We pooled size classes from all plots (Donovan and Welden, 2002). Number of plants within each grouping of cladodes by size dropped off rapidly at larger sizes, so plants were placed into the groups listed above. Because plants were marked individually, we determined annual changes in size for particular plants and grouped them 
TABLE 1-Summary of data for populations of the western prickly pear cactus Opuntia macrorhiza in Boulder County, Colorado, 1998-2005. All plots except 57 were $100 \mathrm{~m}^{2}$; plot 57 was $92 \mathrm{~m}^{2}$ and data presented are scaled to $100 \mathrm{~m}^{2}$.

\begin{tabular}{rcccc}
\hline \hline Plot & $\begin{array}{c}\text { Mean number of } \\
\text { plants } / 100 \mathrm{~m}^{2}(S D)\end{array}$ & $\begin{array}{c}\text { Mean number of } \\
\text { recruits/year }(S D)\end{array}$ & $\begin{array}{c}\text { Recruits surviving } \\
\text { first year }(\%)\end{array}$ & $\begin{array}{c}\text { Mean annual deaths/ } \\
100 \text { plants }(S D)\end{array}$ \\
\hline 28 & $62.6(17.0)$ & $23.6(14.8)$ & 52.6 & $27.5(14)$ \\
52 & $68.9(20.2)$ & $17.4(9.7)$ & 74.4 & $15.0(6.4)$ \\
57 & $138.7(17.8)$ & $40.3(33.8)$ & 75.2 & $21.0(16.2)$ \\
61 & $36.2(12.7)$ & $11.1(7.1)$ & 62.7 & $27.2(10.7)$ \\
102 & $19.3(6.0)$ & $4.5(4.1)$ & 53.8 & $28.6(6.5)$ \\
\hline
\end{tabular}

to determine transition probabilities of the matrix. Whenever a plant subdivided, we considered the central ramet the original plant and any peripheral clones were recorded as vegetative reproduction. As a consequence, new recruits occasionally possessed several cladodes. Values in the top line of the matrix sum the frequencies of new recruits of that size class, combining observed frequencies of recruits whether from seed or from vegetative reproduction.

Results-We followed a total of 841 plants during the study. Mean densities of populations in the five plots were 20-135 plants/100 $\mathrm{m}^{2}$ (Table 1). Within the study period, some populations increased while others decreased (Fig. 1). There was substantial between-year variation as well, with some populations varying nearly $75 \%$ above or below the mean with $50 \%$ variation being common (Fig. 1). There was no correlation of changes in populations among plots (Fig. 1). Percentage change in a population between successive years was not significantly related to precipitation of either year $(r=0.37$ and 0.34 , respectively; $n=7$ ).

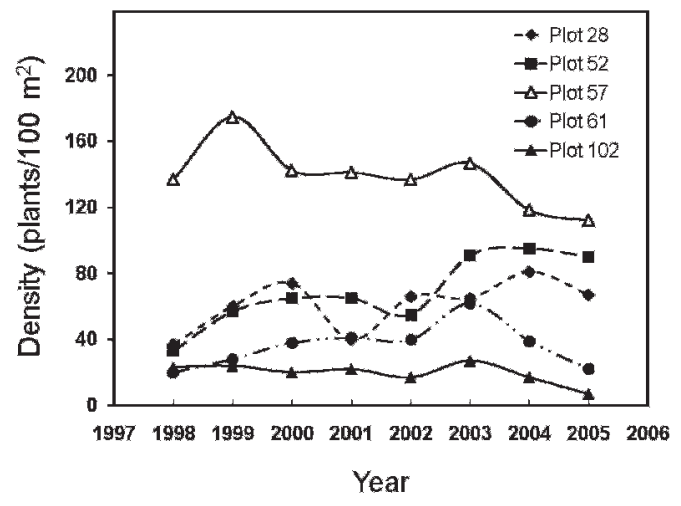

FIG. 1-Density (plants/100 $\mathrm{m}^{2}$ ) of the western prickly pear cactus Opuntia macrorhiza on five $100-\mathrm{m}^{2}$ plots in Boulder County, Colorado, 1998-2005.
Sizes of plants were $1-56$ cladodes. Mean sizes were $3.8,3.6,6.7,5.2,4.5,3.7$, and 3.2 cladodes for 1999-2005, respectively; overall average was 3.6 cladodes. Median sizes of plants for those years were $2,2,4,3,3,3$, and 2 cladodes, respectively, and the grand median was 3 . Total number of cladodes fluctuated substantially as well, being 818, 856, 1,737, 1,538, 1,655, 1,132, and 929, respectively, for those same years. Correlation of mean number of cladodes to all cladodes was $r=0.83$ and to median size $r=0.89$ $(P<0.01, d f=6)$. In terms of number of cladodes present, plants actively grew and contracted.

Size showed a significant, but low, correlation with age. For all plants of known age and size, $r=0.28(n=1,272, P<0.01)$, which leaves most of the variation unexplained. Clearly identified seedlings showed a significant correlation between size and age $(r=0.46, n=112, P<0.01)$, but clearly identified vegetative recruits did not $(r=0.12, n=242, P>0.05)$. Some vegetative rosettes (20 of $120,17 \%$ ) had $\geq 5$ cladodes the first year they were seen, because fission is scored as vegetative reproduction. No seedling was seen with five cladodes before it had lived 3 years.

New plants were recorded as recruits, a total of 605 in 1998-2005. Mean numbers of new plants as a proportion of the population (rate of recruitment) during the study ranged from $23.3 \%$ (4.5 recruits/19.3 plants) in plot 102 to $37.7 \%$ (23.6 recruits/62.3 plants) in plot 28 (column 2 divided by column 1 in Table 1). Annual recruitment ranged from a low of no plant (plot 102 in 2000) to a high of 53 plants (plot 57 in 2003, 47 recruits scaled to $100 \mathrm{~m}^{2}$ ).

Of the 605 recruits, $128(21.2 \%)$ were seedlings and $190(31.4 \%)$ vegetative sprouts. For the remaining 318 recruits, the origin was unknown. Relative frequency of known seedlings and 


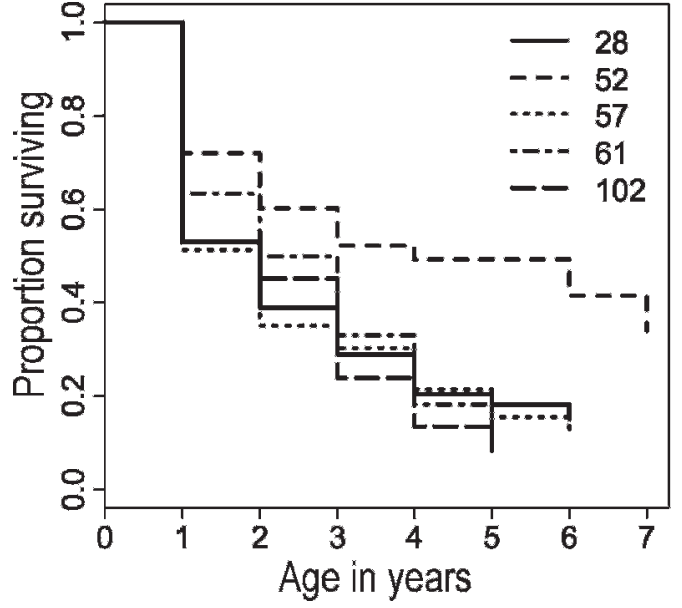

FIG. 2-Survival of the western prickly pear cactus Opuntia macrorhiza on five $100-\mathrm{m}^{2}$ plots sampled in Boulder County, Colorado, as a function of age. The proportion of plants surviving from one year to the next is represented as step functions because the data were collected in discrete time steps (years). Each line represents survival of plants on a plot. The graph suggests that $50 \%$ of plants died in 2 years, with the exception of plot 52 where $50 \%$ of plants died after 4 years.

vegetative recruits varied between year and plots, but, as in the overall average, vegetative recruits generally were more common than seedlings. These figures are tentative because of the unidentified recruits, but seedlings have distinctive morphology that can persist $2-3$ years, so the values are probably conservative because none of the unknowns had morphology of juveniles.

Much of the vegetative reproduction occurred when large clones came apart, following damage from insects, cattle, or fire. Few of these cladodes moved far. Mean distance from a new vegetative recruit to any plant from the previous year was $14.08 \mathrm{~cm}(n=87, S D=9.16)$. Only two clones were $\geq 50 \mathrm{~cm}$ from plants of the previous year ( $2 \%$ of 87 ). In contrast, newly found plants with juvenile foliage (recruits from seed) averaged $62.94 \mathrm{~cm}$ from nearest plant of the previous year $(n=45, S D=24.02)$. Not surprisingly, these numbers are significantly different $(t$-test, $P<$ $0.001, d f=130)$.

Of plants seen for the first time, $65.0 \%$ survived their first year $(n=665$, including all years and all plots). Using the most conservative definitions of seedlings and vegetative recruits, their survival did not differ significantly in the first year: $59.1 \%$ of 110 seedlings and $62.3 \%$ of 173 vegetative recruits survived their first year $\left(\chi^{2}\right.$ $=0.315, d f=2, P>0.05)$.

Rate of survival was lowest within the first year of life, and only ca. $20 \%$ of plants survived $>5$ years in plots 28, 57, 61, and 102 (Fig. 2). According to the Cox proportional-hazards model, mortality in plot 52 was $48 \%$ less than in other plots, which implies that probability of a plant surviving in plot 52 in any year was double that in other plots. The Cox proportional-hazards model is significant (Likelihood-ratio test $=32.7$ on $d f=4, P<0.001, n=597)$. Plants of $O$. macrorhiza are capable of living many years, particularly in good microsites such as in plot 52, but in most instances, they do not.

Across all plots and years, we observed $28.2 \%$ of plants (of 768 for which there were complete data) to flower at least once. Size showed a significant correlation with flowering, but explained little of the variation $(r=0.18, n=1,224, P<0.01)$. Percentage of plants flowering also increased significantly with size of plant: $r=0.95(n=11$ size classes, $P<0.01)$. Flowering was not related to annual precipitation $(r=0.04, P>0.05)$ or rainfall in the growing season $(r=0.02, P>0.05)$. Number of flowers per plant also increased with age $(r=0.13$ for all plants, all years, $P<0.001, n=$ $1,272)$, but more dramatically with size $(r=0.51$, $P<0.001, n=1,272)$.

The size-based matrix model (Table 2) indicated a rate of growth of ca. 1.0, so populations were stable. However, the predicted stable distribution of size is significantly different from that observed, indicating that populations in the field are not at equilibrium (Table 2). This is expected in a variable environment such as the High Plains grassland. Elasticities (Table 2) identify life-history stages that are most important for rate of growth of the population ( $\lambda$; Caswell, 2001). The largest elasticity values for $O$. macrorhiza in this study are transitions involving small life-history classes; for instance, the two largest elasticity values are transition from one cladode to $2-3$ cladodes and of 2-3 cladode plants remaining in the same stage class for 2 consecutive years. This suggests that, while currently stable, changes in survival of smaller plants quickly could change trajectories of populations.

Discussion-Opuntia macrorhiza is a shortlived perennial of western grasslands. This study demonstrated that, in contrast to most other 
TABLE 2-Size-based matrices for populations of the western prickly pear cactus Opuntia macrorhiza in Boulder County, Colorado. Also presented are average percentage of plants in each size class, predicted rate of growth $(\lambda)$, and predicted stable size distribution for each size class. Size is measured as number of cladodes. Observed size classes are significantly different from the stable age distribution ( $G$ test, $G_{(\text {adjusted })}=45.85, d f=4, P<0.001$ ).

\begin{tabular}{|c|c|c|c|c|c|}
\hline \multirow[b]{2}{*}{ Size class } & \multicolumn{5}{|c|}{ Size class } \\
\hline & 1 & $2-3$ & $4-7$ & $8-15$ & $>15$ \\
\hline \multicolumn{6}{|l|}{ Transition matrix $(\lambda=1.018)$} \\
\hline 1 & 0.170 & 0.188 & 0.811 & 2.828 & 7.814 \\
\hline $2-3$ & 0.318 & 0.448 & 0.227 & 0.179 & 0.138 \\
\hline $4-7$ & 0.080 & 0.152 & 0.337 & 0.250 & 0.150 \\
\hline $8-15$ & 0.006 & 0.017 & 0.133 & 0.297 & 0.238 \\
\hline$>15$ & 0.000 & 0.005 & 0.017 & 0.113 & 0.250 \\
\hline Observed average $(\%)$ & 7 & 47 & 25 & 16 & 5 \\
\hline Predicted stable size distribution & 0.465 & 0.334 & 0.147 & 0.042 & 0.012 \\
\hline \multicolumn{6}{|l|}{ Elasticity matrix } \\
\hline 1 & 0.038 & 0.030 & 0.058 & 0.059 & 0.045 \\
\hline $2-3$ & 0.117 & 0.118 & 0.026 & 0.006 & 0.001 \\
\hline $4-7$ & 0.064 & 0.088 & 0.086 & 0.019 & 0.003 \\
\hline $8-15$ & 0.010 & 0.022 & 0.073 & 0.047 & 0.010 \\
\hline$>15$ & 0.000 & 0.011 & 0.017 & 0.032 & 0.019 \\
\hline
\end{tabular}

species of Opuntia (Godìnez-Alvarez et al., 2003; Reyes-Agüero et al., 2006), most individuals lived $<4$ years. Mortality was highest for new recruits (seedlings and vegetative). Mortality decreased with age, and some individuals probably live 2 decades. Clones of O. macrorhiza are potentially immortal and are mobile, because isolated cladodes can root. A minimum of $40.8 \%$ of new plants were produced vegetatively by rooting of isolated cladodes or separation of established cladodes. Thus, a single genotype could live much longer than 20 years if clonally produced plants were successful.

In many species of Opuntia, reproduction by seeds is infrequent (Godínez-Álvarez et al., 2003; Reyes-Agüero et al., 2006; Piña et al., 2007). Relative success of reproduction by vegetative means and by seeds for Opuntia rastera depended on habitat (Mandujano et al., 1998, 2001). Success of recruitment of $O$. macrorhiza in our study was $>50 \%$ (Table 1), which is an order of magnitude higher than reported for most species of cacti (Palleiro et al., 2006; ReyesAgüero et al., 2006). This may reflect relatively mesic conditions in grasslands compared to deserts. It also is possible that because we surveyed only once annually, we missed many early season unsuccessful recruits. However, maintenance of populations in short-lived spe- cies requires frequent recruitment into the population, so this difference from other Opuntia is essential to maintain a short lifespan.

Size and reproduction increased with age, as in most plants. However, the size-based approach is complicated: O. macrorhiza frequently decreased in size (e.g., $55 \%$ of changes in size during 2000-2001 were decreases); O. macrorhiza can grow exponentially (some plants increased in size by $50 \%$ ). We observed this magnitude of increase for all size classes. This is because cladodes are modified stems, not leaves, and should apply to most if not all species of Opuntia (Reyes-Agüero et al., 2006). Nevertheless, we detected a stronger relationship of flowering to size than to age. This too is expected; data are more abundant for size than age, but where age and size have been compared, flowering is usually more correlated with size than with age (e.g., Sarkuhan et al., 1984; Kachi and Hirose, 1985; Pfeifer et al., 2006).

Years in our study included significant drought (National Oceanographic and Atmospheric Administration, 1995-2005). Size of populations and frequency of flowering did not decrease in response to drought (Fig. 1). This probably reflects that in this dry grassland, cacti are limited more by competition or herbivory than by water (e.g., Burger and Louda, 1995; Mandu- 
jano et al., 1998; Reyes-Agüero et al., 2006). All five populations were stable through the study period, although there was substantial variation among years and sites. This is consistent with predictions of the matrix model (asymptotic rate of growth of the population, $\lambda \approx 1$ ). Plants of $O$. macrorhiza have evolved in a continuous grassland that is now divided into relatively small islands of prairie. Thus, persistence of $O$. macrorhiza over the next decades will depend on the importance of outcrossing and ability to invade new areas in the fragmented grasslands, but for the present, within these grassland fragments, it is reproducing effectively.

We thank the City of Boulder Open Space and Mountain Parks and especially L. Riedel, for help throughout this project. Partial funding was provided by City of Boulder Open Space small grants program. G. A. Norrmann, Instituto de Botanica, Corrientes, Argentina, kindly translated the abstract.

\section{Literature Cited}

Anderson, E. F. 2001. The cactus family. Timber Press, Portland, Oregon.

BennetT, B. C. 1997. Vegetation on the City of Boulder Open Space grasslands. Ph.D. dissertation, University of Colorado, Boulder.

Benson, L. 1992. The cacti of the United States and Canada. Stanford University Press, Palo Alto, California.

Bock, J. H., ANd C. E. Bock. 1998. Tallgrass prairie: remnants and relicts. Great Plains Research 8: 213-230.

Bowers, J. E. 1996. More flowers or new cladodes? Environmental correlates and biological consequences of sexual reproduction in a Sonoran Desert prickly pear cactus, Opuntia engelmannii. Bulletin of the Torrey Botanical Club 123:34-40.

Burger, J. C., AND S. M. LoudA. 1995. Interaction of diffuse competition and insect herbivory in limiting brittle prickly pear cactus, Opuntia fragilis (Cactaceae). American Journal of Botany 82:1558-1566.

Caswell, H. 2001. Matrix population models. Sinauaer Associates, Inc., Publishers, Sunderland, Massachusetts.

Cox, D. R., ANd D. OAKEs. 1984. Analysis of survival data. Chapman and Hall, London, United Kingdom.

Donovan, T. M., And C. W. Welden. 2002. Spreadsheet exercises in ecology and evolution. Sinauaer Associates, Inc., Publishers, Sunderland, Massachusetts.

Esparza-Olguín, L., T. Valverde, and E. Vilchis-Anaya. 2002. Demographic analysis of a rare columnar cactus (Neobuxbaumia macrocephala) in the Tehuacan Valley, Mexico. Biological Conservation 103:349-359.
Godínez-Álvarez, H., T. Valverde, and P. Ortega-Baes. 2003. Demographic trends in the Cactaceae. Botanical Review 69:173-203.

Kachi, N., and T. Hirose. 1985. Population dynamics of Oenothera glazioviana in a sand-dune system with special reference to the adaptive significance of sizedependent reproduction. Journal of Ecology 73: 887-901.

Kalbfleish, J. D., And R. L. Prentice. 1990. The statistical analysis of failure time data. John Wiley and Sons, Inc., New York.

Mandujano, M. C., J. Gloubov, and L. F. Huenneke. 2007. Effect of reproductive modes and environmental heterogeneity in the population dynamics of a geographically widespread clonal desert cactus. Population Ecology 49:141-153.

Mandujano, M. C., C. Montaña, and L. E. Eguiarte. 1996. Reproductive ecology and inbreeding depression in Opuntia rastrera (Cactaceae) in the Chihuauan Desert: why are sexually derived recruitments so rare? American Journal of Botany 83:63-70.

Mandujano, M. C., C. Montaña, I. Méndez, and J. Golubov. 1998. The relative contribution of sexual reproduction and clonal propagation in Opuntia rastrera from two habitats in the Chihuahuan Desert. Journal of Ecology 86:911-921.

Mandujano, M. C., C. Montaña, M. Franco, J. Golubov, and A. Flores-Martínez. 2001. Integration of demographic annual variability in a clonal desert cactus. Ecology 82:344-359.

National Oceanographic and Atmospheric AdministraTION. 1995-2005. Colorado. Climatological Data 1995-2005:1-30.

Palleiro, N., M. C. Mandujano, and J. Golubov. 2006. Aborted fruits of Opuntia microdasys (Cactaceae): insurance against reproductive failure. American Journal of Botany 93:505-511.

Pfeifer, M., W. Heinrich, and G. Jetschke. 2006. Climate, size and flowering history determine flowering pattern in an orchid. Botanical Journal of the Linnean Scoiety 151:511-526.

Piña, H. H., C. Montaña, and M. C. Mandujano. 2007. Fruit abortion in the Chihuahuan-Desert endemic cactus Opuntia microdasys. Plant Ecology 193:305-313.

Pinkava, D. J. 2003. Opuntia. Pages 123-148 in Flora of North America north of Mexico. Volume 4. Magnoliophyta: Caryophyllidae, part 1. Oxford University Press, New York.

R Development Core Team. 2006. R: a language and environment for statistical computing. R Foundation for Statistical Computing, Vienna, Austria.

Rae, J. G., And T. A. Ebert. 2002. Demography of the endangered fragrant prickly apple cactus, Harrisia fragrans. International Journal of Plant Sciences 163:631-640.

Reyes-Agüero, J. A., J. R. Aguirre R, and A. ValienteBanuet. 2006. Reproductive biology of Opuntia: a review. Journal of Arid Environments 64:549-585. 
Sarkuhan, J., M. Martinez-Ramos, and D. Pinero. 1984. The analysis of demographic variability at the individual level and its population consequences. Pages 83-106 in Perspectives in plant population ecology ( $\mathrm{R}$. Dizro and J. Sarkuhan, editors). Sinauer Associates, Inc., Publishers, Sunderland, Massachusetts.

Schmalzel, R. J., F. W. Reichenbacher, and S. Rutman. 1995. Demographic study of the rare Corypantha robbinsorum (Cactaceae) in southeastern Arizona. Madroño 42:332-348.

Valverde, P. L., and J. A. Zavala-Hurtado. 2006. Assessing the ecological status of Mammillaria pectinifera Weber (Cactaceae), a rare and threatened species endemic of the Tehuacán-Cuicatlán region of central Mexico. Journal of Arid Environments 64:193-208.

Zavala-Hurtado, J. A., And A. Díaz-Solís. 1995. Repair, growth, age and reproduction in the giant columnar cactus Cepalocereus columna-trajani (Karwinski ex. Pfeiffer) Schumann (Cactaceae). Journal of Arid Environments 31:21-31.

Submitted 20 June 2009. Accepted 6 August 2010. Associate Editor was Janis K. Bush. 